\title{
Distinct roles for PP1 and PP2A in the Neurospora circadian clock
}

Yuhong Yang, ${ }^{1}$ Qun He, ${ }^{1}$ Ping Cheng, ${ }^{1}$
Philip Wrage,

${ }^{1}$ Department of Physiology, University of Texas Southwestern Medical Center, Dallas, Texas 75390, USA; ${ }^{2}$ Department of Plant Pathology and Microbiology, Faculty of Agricultural Food and Environmental Quality Sciences, The Hebrew University of Jerusalem, Rehovot 76100, Israel

Phosphorylation of the Neurospora circadian clock protein FREQUENCY by several kinases promotes its degradation and is important for the function of the circadian feedback loop. Here, we show that FRQ is less stable in a ppp-1 (catalytic subunit of PP1) mutant, resulting in its advanced phase and short period. In contrast, FRQ stability is not altered in a $\mathbf{r g b - 1}$ (a regulatory subunit of PP2A) mutant, but levels of frq protein and mRNA are low, resulting in a low-amplitude and longperiod oscillation of the clock. Furthermore, PP1 and PP2A expressed in Neurospora can dephosphorylate the endogenous FRQ in vitro, suggesting that these two phosphatases may differentially regulate FRQ and, consequently, the behavior of the circadian clock.

Supplemental material is available at http://www.genesdev.org.

Received September 15, 2003; revised version accepted December 15, 2003.

Reversible phosphorylation is an important regulatory mechanism for many biological processes in eukaryotic organisms. The phosphorylation state of a protein is controlled dynamically by protein kinases and phosphatases. Previous studies have demonstrated that phosphorylation of circadian clock proteins is an essential posttranscriptional mechanism in the regulation of circadian clocks (Dunlap 1999; Young and Kay 2001). Several kinases, including casein kinase I (CKI) and CKII, have been shown to phosphorylate and regulate the key clock components in eukaryotic systems (Kloss et al. 1998; Sugano et al. 1999; Lowrey et al. 2000; Gorl et al. 2001; Yang et al. 2002).

FREQUENCY (FRQ), WHITE COLLAR-1 (WC-1), and WC-2 proteins are three key components in the Neurospora frq-wc-based circadian oscillator (Loros and Dunlap 2001). In addition to being the circadian blue light photoreceptor (Froehlich et al. 2002; He et al. 2002), in the dark, WC-1 forms a heterodimeric complex with WC-2 through their PAS domains and activate $f_{r} q$ transcription by binding its promoter (Crosthwaite et al. 1997; Talora

[Keywords: frequency; phosphorylation; phosphatase; PP1; PP2A] ${ }^{3}$ Corresponding author.

E-MAIL Yi.Liu@UTSouthwestern.edu; FAX (214) 648-7891. Article and publication are at http://www.genesdev.org/cgi/doi/10.1101/ gad.1152604 et al. 1999; Cheng et al. 2001b, 2002, 2003; Froehlich et al. 2003). FRQ, the negative element of the feedback loop, inhibits its own transcription through interactions with the WC complex (Aronson et al. 1994; Cheng et al. 2001a; Denault et al. 2001; Froehlich et al. 2003). FRQ protein is immediately phosphorylated after its synthesis and becomes extensively phosphorylated prior to its degradation by the ubiquitin/proteasome pathway (Garceau et al. 1997; Liu et al. 2000; He et al. 2003). In constant darkness, FRQ is not only robustly rhythmic in its cellular concentration, but also in its phosphorylation states, so that the level and the phosphorylation status of FRQ define the time of the clock during a circadian cycle (Garceau et al. 1997).

Phoshorylation of FRQ is mediated by CKI, CKII, and a calcium/calmodulin-dependent kinase (Gorl et al. 2001; Yang et al. 2001, 2002, 2003). Molecular, genetic, and biochemical experiments have shown that phosphorylation of FRQ has several functions. Mutations of the FRQ phosphorylation sites lead to the stabilization of the FRQ protein and long period rhythms of the clock (Liu et al. 2000; Gorl et al. 2001; Yang et al. 2003). In strains with the CKII catalytic subunit or one of its regulatory subunits disrupted, the protein level of FRQ is high and more stable, and the clock function is either completely abolished or severely affected (Yang et al. 2002, 2003). These data indicate that phosphorylation of FRQ promotes its degradation. In addition, we have shown previously that the CKII-mediated FRQ phosphorylation regulates the FRQ-WC interaction and is important for the closing of the circadian negative feedback loop (Yang et al. 2002, 2003). In a CKII mutant, frq mRNA levels are high despite the high FRQ levels.

In contrast to the well-characterized clock functions of several kinases in various circadian systems, little is known about the potential roles of protein phosphatases. Unlike the large number of protein kinases in eukaryotes, there are only a few highly conserved catalytic subunits of protein phosphatases (Virshup 2000; Cohen 2002). Protein phosphatase 1 (PP1) and PP2A are two major eukaryotic serine/threonine protein phosphatases. The catalytic subunits of the Neurospora PP1 and PP2A are $87 \%$ and $85 \%$ identical to their homologs in human, respectively. Protein phosphatases carry out their diverse cellular functions with the help of a large number of regulatory proteins, which form heteromultimeric complexes with the catalytic subunits and regulate their activity, specificity, and cellular localization. In this study, we show that PP1 and PP2A are important regulators of the Neurospora circadian clock. Surprisingly, down-regulation of these two phosphatases leads to distinct phenotypes of the circadian clock.

\section{Results and Discussion}

To investigate the possible roles of PP1 and PP2A in the Neurospora circadian clock, we screened for mutants in which the catalytic subunit or a regulatory subunit of PP1 or PP2A is mutated. Because the catalytic subunits of PP1 and PP2A (encoded for by the ppp-1 and pph-1 genes, respectively) are essential for cell survival in Neurospora and other eukaryotes (Yatzkan and Yarden 1995; Zeke et al. 2003), we used repeat-induced point mutation (RIP; Cambareri et al. 1989) to obtain partially functional 
mutants of these two genes. RIP introduces random, but exclusively G-C to A-T point mutations during sexual cycle. Whereas we are unable to obtain any viable mutant of $p p h-1$, one mutant of the $p p p-1$ gene $\left(p p p-1^{R I P}\right)$ was isolated. Sequencing of endogenous $p p p-1$ gene revealed four missense mutations (all $\mathrm{G}$ to $\mathrm{A}$ mutations) in the coding region of the gene, that is, Asp 71-Asn, Glu 84-Lys, Met 183-Ile, and Val 223-Ile. Among them, Asp 71 is conserved in all known PP1 catalytic subunit genes, whereas Glu 84, Met 183, and Val 223 are variable in some PP1 homologs. To examine whether these mutations led to the decrease of the phosphatase activity of PP1, phosphatase assay (see supplemental materials) was performed using extracts prepared from cultures grown in LL, a condition that the clock is not running. The ${ }^{32} \mathrm{P}$-labeled phosphorylase a is used as the substrate of the assay in the presence or absence of inhibitor-2, a specific protein inhibitor for PP1 (Krebs and Fischer 1962; Yatzkan et al. 1998; Cohen 2002). As shown in Figure 1A, the inhibitor-2-sensitive phosphatase acitivity was significantly reduced in the $p p p-1^{R I P}$ strain, indicating that the mutations resulted in a partial functional PPP-1 protein. The $p p p-1^{R I P}$ strain exhibits near

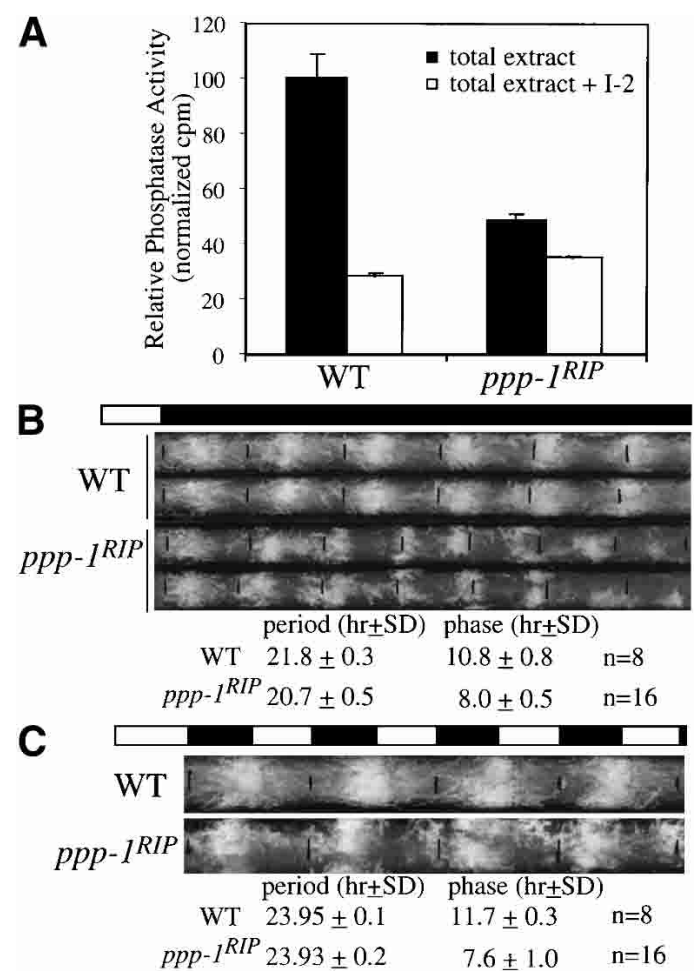

Figure 1. Circadian conidiation rhythms of the $p p p-1^{R I P}$ strain show advanced phase and short period phenotypes. (A) Phosphatase activity assay showing the reduction of PP1 activity in the $p p p-1^{R I P}$ strain. Cultures were cultured and harvested in LL. I-2: assay containing $100 \mathrm{U}$ of inhibitor-2. Error bars, standard deviations. (B) Race tube assay showing the circadian conidiation rhythms of the wild-type and the $p p p-1^{R I P}$ strains in DD. The black lines mark the growth fronts at $24-\mathrm{h}$ intervals. The calculated period length and phase are shown below. (SD) Standard deviation. $(C)$ Race tube assay in LD cycles. To show the difference of the position of the conidiation peaks between the two strains, the image of the $p p p-1^{R I P}$ mutant was enlarged so that it showed similar daily growth distance as the wild-type strain. normal appearance in slants and its growth rate is only $\sim 20 \%$ slower than the wild-type strain (Fig. 1B), suggesting that the $\sim 70 \%$ decrease in PP1 activity did not severely affect its essential cellular functions and that the amount of PPP-1 is probably in excess in a wild-type strain, or, alternatively, other PPs can partially compensate for the reduction in PP1 activity.

Examination of the circadian conidiation rhythm in constant condition (constant darkness, DD) by race tube assay revealed that the period length of the circadian clock in the $p p p-1^{R I P}$ strain was $\sim 1$ h shorter than that of the wild-type strain $(P$ value $=2.5 \mathrm{E}-06$; Fig. $1 \mathrm{~B})$. More prominently, the phase of the first conidiation band in the mutant was $\sim 3 \mathrm{~h}$ advanced compared with that of the wild-type strain $(P$ value $=6.5 \mathrm{E}-11)$. To further confirm the advanced phase of the $p p p-1^{R I P}$ strain, race tube assays were performed under light/dark cycles (12 h dark/ $12 \mathrm{~h}$ light). As seen in Figure 1C, although the period of the mutant was entrained to $24 \mathrm{~h}$ by the light/dark cycles, the phases of the conidiation peaks in the mutants were $\sim 4 \mathrm{~h}$ earlier than those of the wild-type $(P$ value $=2.3 \mathrm{E}-08)$.

To monitor the molecular rhythms in DD, Western blot and Northern analyses were performed to examine the expression of FRQ protein and $f_{r} q \mathrm{mRNA}$ in the $p p p$ $1^{R I P}$ strain. The rhythms of protein level and phosphorylation states of FRQ were robust in the $p p p-1^{R I P}$ strain, but a significantly advanced phase was observed as compared with the wild-type strain (Fig. 2A; Supplemental Fig. 1). At DD12 (12 h in constant darkness) and DD32, when FRQ proteins in the wild-type strain were extensively phosphorylated, the newly synthesized hypophosphorylated FRQ forms were seen in the mutant, indicating an advanced phase. Taken together, these data suggest that PP1 is a regulator of the Neurospora circadian clock.

Because one of the roles of protein phosphorylation in the Neurospora circadian clock is to promote FRQ degradation, we compared the degradation rates of FRQ after the addition of the protein synthesis inhibitor, cycloheximide (CHX; Liu et al. 1997), between the wild-type and the $p p p-1^{R I P}$ trains. As shown in Figure $2 \mathrm{~B}$, the disappearance of FRQ in the $p p p-1^{R I P}$ strain was faster than in the wild-type strain. Similar results were obtained in seven independent CHX experiments (Fig. 2B) and in experiments that measured the FRQ degradation rate after a light to dark transition (data not shown). Interestingly, the faster FRQ degradation in the mutant appears to be mostly due to the lack of a lag between the addition of CHX and FRQ degradation in the first $3 \mathrm{~h}$ of the CHX treatment. Together, these data indicate that FRQ is less stable in the $p p p-1^{R I P}$ strain, explaining its advanced phase and the shorter period of the clock.

The eukaryotic PP2A holoenzyme consists of a tightly associated core complex containing the PP2A catalytic subunit (PPH-1 in Neurospora; $\mathrm{C}$ subunit) and a scaffolding subunit (A subunit). This dimeric core can form trimeric complexes with a third variable regulatory subunit (B subunit), which regulates the activity, specificity, and the localization of the holoenzyme (Virshup 2000). To study the role of one of the PP2A holoenzymes in the Neurospora circadian clock, we studied the circadian clock phenotype in a mutant $\left(r g b-1^{R I P}\right)$, in which one of the Neurospora PP2A B subunits (RGB-1) had been disrupted by RIP (Yatzkan and Yarden 1999). RGB-1 is a highly conserved B subunit of PP2A found in fungi, 

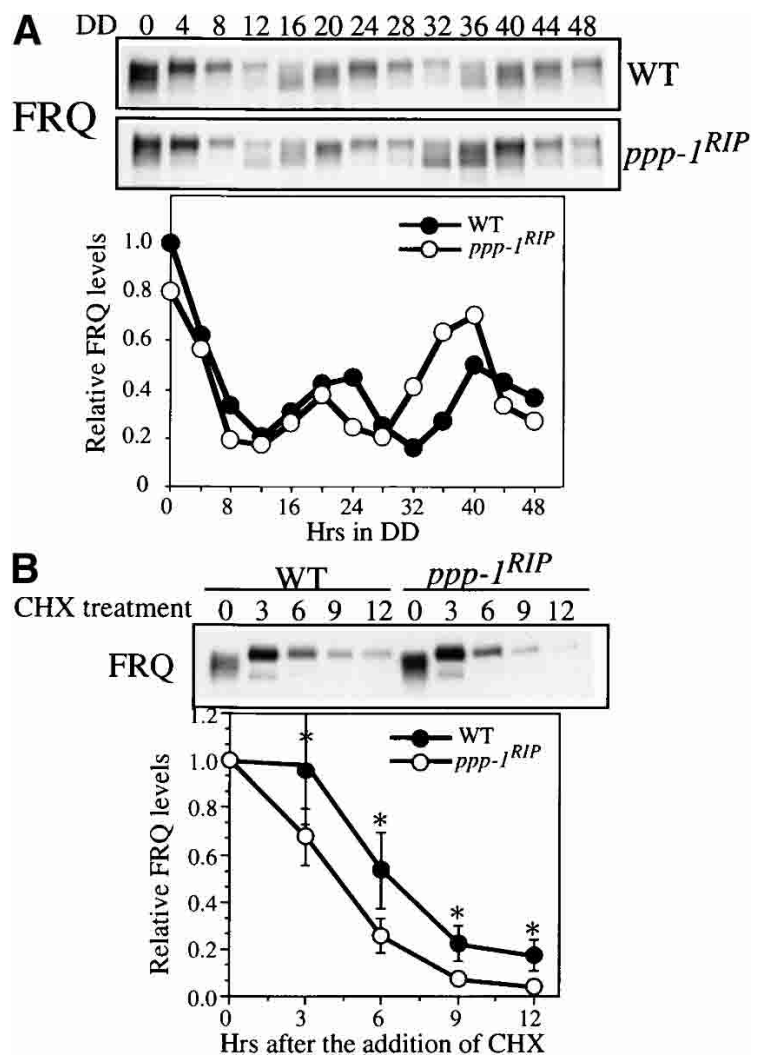

Figure 2. Circadian rhythm of FRQ expression and its stability in the wild-type $(\bullet)$ and $p p p-1^{R I P}(O)$ strains. $(A)$ Western blot analysis showing the circadian oscillation of FRQ in DD. Densitometric analysis of the Western blot results is shown at bottom. Two independent experiments were performed and similar results were obtained (see Supplemental Fig. 1). (B) Western blot analysis showing that FRQ is less stable in the $p p p-1^{R I P}$ strains after the addition of CHX $(10 \mu \mathrm{g} / \mathrm{mL})$. Cultures were grown in LL. Densitometric analysis of the Western blot results from seven independent experiments is shown at bottom. Error bars, standard deviations. $\left({ }^{*}\right) P$ values for $3,6,9$, and $12 \mathrm{~h}$ are 0.02 , $0.003,0.001$, and 0.0009 , respectively.

plants, insects, and mammals. The disruption of the $r g b-1$ gene led to slow growth, abnormal morphology, and defects in several developmental processes. Sequencing of the RIP-inactivated allele of $r g b-1$ revealed that in addition to many missense mutations, there are two premature stop codons at amino acids 156 and 219. Thus, this mutant is not expected to make any functional RGB-1 protein. Phosphatase assays showed that the total phosphatase activity was $\sim 20 \%$ lower in the $r g b-1^{R I P}$ strain than in the wild-type (Fig. 3A). This data suggests that the loss of RGB-1 protein lead to the decrease of the PP2A activity.

Because of the slow growth rate $1-10 \%$ of the wild type) and poor production of aerial hyphae and conidia, the circadian conidiation rhythm in the $r g b-1^{R I P}$ strain was not easily observed by race tube assay. However, hyphae-banding rhythms could be seen in some race tubes in constant darkness (Fig. 3B). These banding rhythms did not appear to exhibit regular period length; at times, the period was $\sim 24 \mathrm{~h}$, but sometimes periods were significantly longer than $1 \mathrm{~d}$. This irregular banding pattern suggests that the circadian clock probably does not function properly in the $r g b-1^{R I P}$ strain.

To examine whether the FRQ degradation rate was increased in the $r g b-1^{R I P}$ strain, we measured the degradation rates of FRQ after the addition of CHX (Fig. 3C) or following a light to dark transition (data not known). Our results indicated that the degradation rate of FRQ was not increased in the $r g b-1^{R I P}$ strain.

Rhythmic Western blot analyses were then performed to examine whether the clock was functional at the molecular level in the mutant strain. As shown in Figure 4A, a low-amplitude FRQ protein oscillation was seen in the mutant in constant darkness, but the period of the oscillation was $\sim 4-6$ h longer than that of the wild type. In addition, the overall levels of FRQ protein in DD in the $r g b-1^{R I P}$ strain were significantly lower than those in the wild-type strain. Similar results were obtained in multiple independent experiments.

Northern blot analysis was performed to examine whether the low levels of FRQ protein was due to the low levels of $f r q$ mRNA. The level of $f r q$ mRNA was significantly lower in the $r g b-1^{R I P}$ strain in constant darkness, but a robust rhythm of $f r q$ levels was not evident in the 2-d experiment ( $f r q$ may have a low amplitude oscillation; Fig. 4B,C; Supplemental Fig. 2). For the

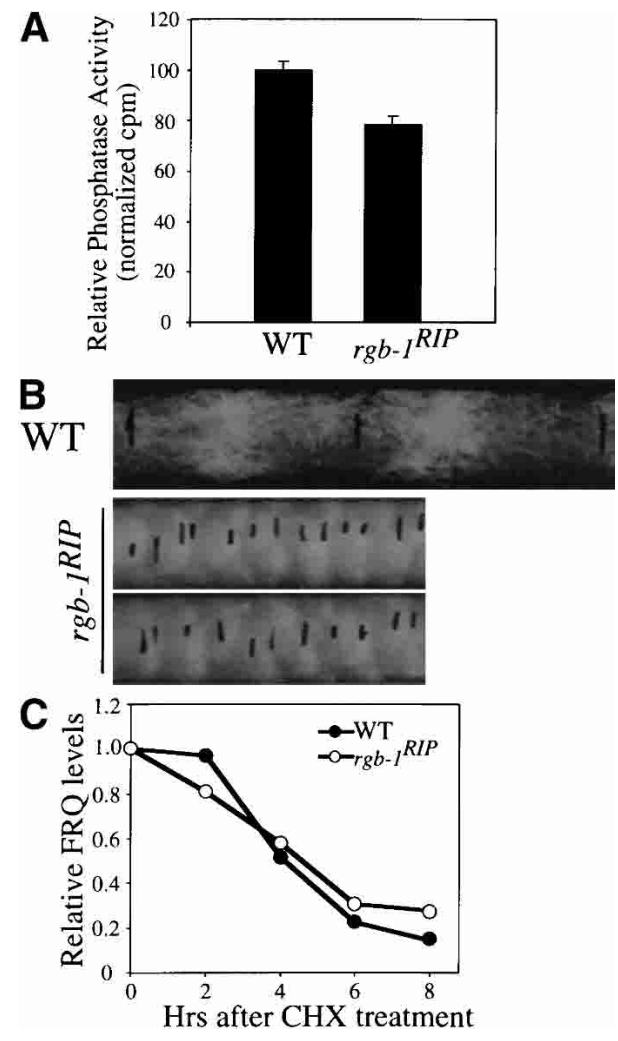

Figure 3. Reduction of PP2A activity and the altered circadian conidiation rhythm in the $r g b-1^{R I P}$ strain. $(A)$ Phosphatase activity assay showing the reduction of phosphatase activity in the $r g b-1^{R I P}$ strain. $(B)$ Race tube assay showing the circadian conidiation rhythms of the wild-type and $r g b-1^{R I P}$ strains in DD. Representative results were shown. The black lines mark the growth fronts at 24-h intervals. $(C)$ Western blot analysis comparing the stability of FRQ after CHX treatment in the wild-type $(\bullet)$ and $r g b-1^{R I P}(O)$ strains. 
A
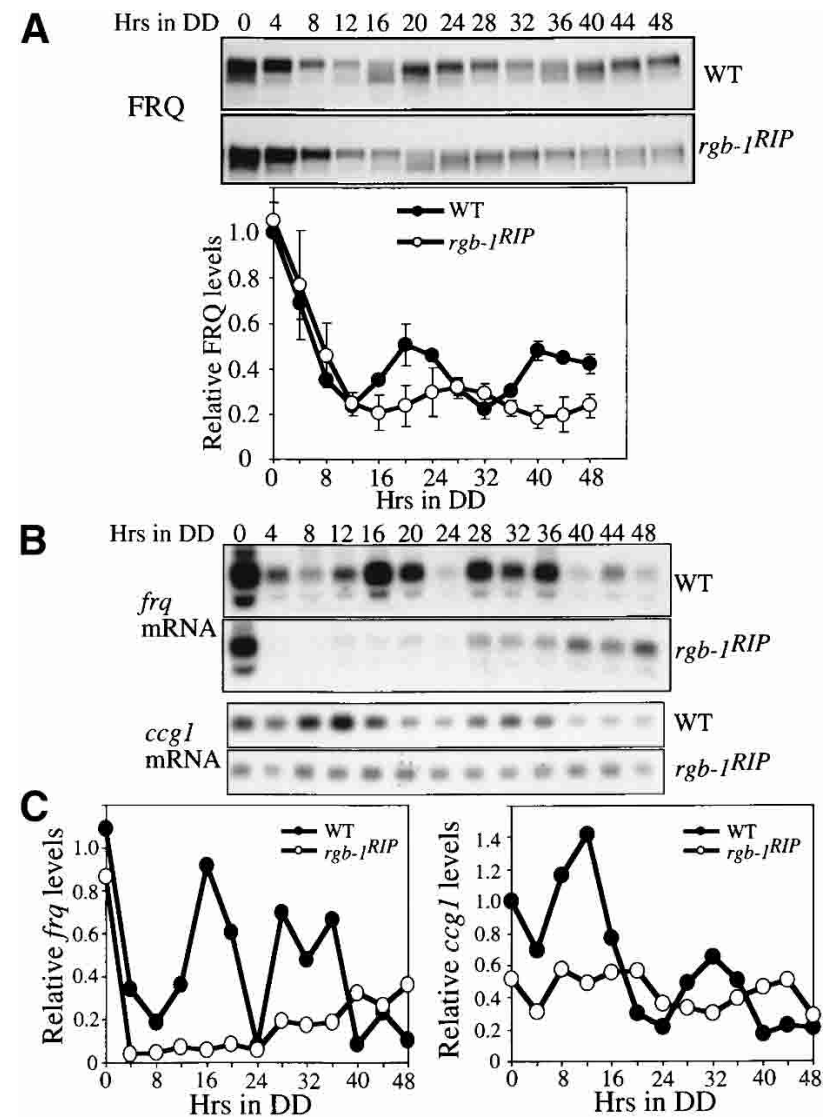

Figure 4. Altered circadian rhythms of FRQ, $f r q$, and $c c g-1$ in the $r g b-1^{R I P}$ strain. (A) Western blot analysis showing the oscillation of FRQ protein in DD. Densitometric analysis of the Western blot results from three independent experiments is shown at bottom. (O) Wild type; (O) $r g b-1^{R I P}$. (B) Northern blot analysis showing the expression of $f r q$ and $c c g-1$ in DD in the wild-type and $r g b-1^{R I P}$ strains. Two independent experiments were performed and similar results were obtained (Supplemental Fig. 2). (C) Densitometric analysis of the results shown in $B$. (๑) Wild type; (O) $r g b-1^{R I P}$.

clock-controlled gene, $c c g$-1, a low-amplitude long period rhythm was seen in the mutant strain. Taken together, these data suggest that the circadian clock function was severely compromised in the $r g b-1^{R I P}$ strain due to a partial loss-of-function of PP2A. Thus, PP2A is also important for the regulation of the Neurospora circadian clock.

How do PP1 and PP2A regulate the Neurospora clock? The increase of FRQ degradation rate in the $p p p-1^{R I P}$ strain suggests that PP1 may directly dephosphorylate FRQ to inhibit its degradation. On the other hand, the low levels of $f r q$ RNA and FRQ protein in the $r g b-1^{R I P}$ strain suggest that the normal circadian feedback loop is impaired in this mutant. Thus, it is likely that PP2A may also dephosphorylate FRQ directly. To test these possibilities, Myc-tagged PPP-1 (Myc-PPP-1) or PPH-1 (Myc-PPH-1) was expressed in a wild-type Neurospora strain (wild type, Myc-PPP-1 or wild type, Myc-PPH-1). To examine whether these Myc-tagged phosphatases expressed in Neurospora can dephosphorylate the endogenously expressed phosphorylated FRQ, total extracts of either strain were mixed with extracts of a fr $q$ null strain expressing the Myc-tagged FRQ protein ( $f r q^{10}{ }^{1}$, Myc-FRQ; Cheng et al. 2001a). As a negative control, the extracts of the $f r q^{10}$, Myc-FRQ strain were mixed with a wild-type strain (containing no Myc-tagged protein). After immunoprecipitation using Myc antibody, they were incubated in phosphatase assay buffer. As shown in Figure $5 \mathrm{~A}$, the inclusion of the Myc-PPP-1 extracts led to the reduction of the extensively phosphorylated Myc-FRQ species. The inclusion of the Myc-PPH-1 also led to the gel mobility-shift changes of Myc-FRQ (Fig. 5B). However, unlike that observed in the extracts containing Myc-PPP-1, the presence of Myc-PPH-1 resulted in the appearance of hypophosphorylated FRQ species that were not normally seen in the control sample. Such hypophosphorylated FRQ forms were similar to those previously observed in the CKII mutants or when FRQ was treated by $\lambda$ phosphatase (Garceau et al. 1997; Yang et al. 2002). Similar results were obtained in three independent experiments. These data suggest that both PP1 and PP2A expressed in Neurospora can directly dephosphorylate endogenous FRQ in vitro. The difference in Myc-FRQ phosphorylation patterns after PP1 or PP2A treatment suggests that these phosphatases might dephosphorylate FRQ at distinct sites.

To obtain in vivo evidence that FRQ is dephosphorylated by PP1 or PP2A, we compared the FRQ phosphorylation profiles of the phosphatase mutants and the wildtype strain in LL, a condition in which FRQ is evenly phosphorylated. No significant differences in FRQ phosphorylation profiles were observed between the wildtype and $p p p-1^{R I P}$ strains, probably due to the residual PP1 activity in the mutant. The near-normal growth and developmental phenotypes of the $p p p-1^{R I P}$ strain suggest that the function of PP1 was not severely impacted in the mutant. On the other hand, a hyperphosphorylated

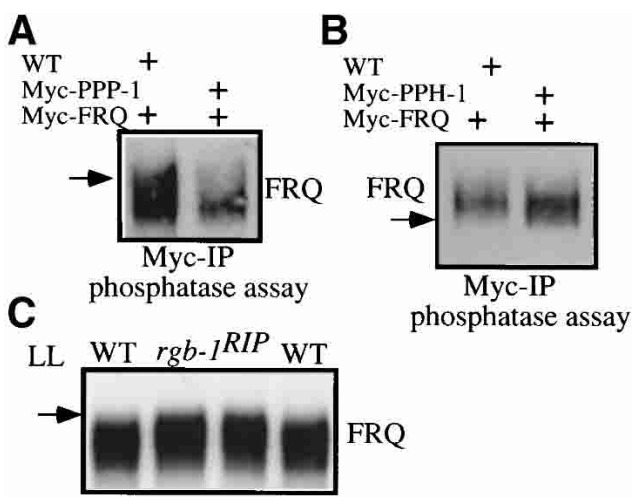

Figure 5. Dephosphorylation of Myc-FRQ by the Neurospora expressed Myc-PPP-1 and Myc-PPH-1. $(A, B)$ The extracts of fr $q^{10}$, Myc-FRQ strain was mixed with the extracts of the wild type, Myc-PPP-1, wild type, Myc-PPh-1, or wild-type strain. Cells were grown in LL. Immunoprecipitation (IP) was then performed using a c-Myc monoclonal antibody. Afterward, the IP products were incubated in phosphatase buffer and Western blot analysis was performed. The arrow in $A$ marks the extensively phosphorylated Myc-FRQ species, while it indicates the hypophosphorylated FRQ forms in $B .(C)$ Comparison of the FRQ phosphorylation profiles in the wild-type and $r g b-1^{R I P}$ strains. Cultures were grown in LL. The arrow indicates the hyperphoshorylated FRQ species seen in the $r g b-1^{R I P}$ strains. 
FRQ species that was not normally present in the wildtype strain was seen in the $r g b-1^{R I P}$ strain (Fig. 5C), suggesting that FRQ is a PP2A substrate in vivo. No significant changes in WC-1 and WC-2 phosphorylation patterns were detected in the mutants (Supplemental Fig. 3), but it is possible that the changes are subtle and could not be detected by Western analysis.

The evidence presented here indicates that PP1 and PP2A have different roles in the regulation of the Neurospora circadian clock. PP1 influences the clock by regulating the stability of FRQ, a role that is predicted from the function of FRQ phosphorylation in promoting FRQ degradation. Unlike PP1, the PP2A holoenzyme containing RGB-1 does not appear to play a role in regulating FRQ stability. In the $r g b-1^{R I P}$ strain, the levels of FRQ protein and frq mRNA are low, and the clock oscillates with a low amplitude and long period. The low levels of FRQ and $f r q$ are in contrast to what was observed previously in a CKII mutant (Yang et al. 2002), suggesting that the function of PP2A opposes that of CKII, probably by preventing the closing of the negative feedback loop. The direct dephosphorylation of the endogenous FRQ by the Neurospora expressed PP1 and PP2A in vitro and changes in FRQ phosphorylation profile in the $r g b-1^{R I P}$ strain further suggest that both PP1 and PP2A may regulate the clock by desphosphorylating FRQ. Therefore, PP1 and PP2A may function in coordination with the FRQ kinases to determine the phosphorylation status of FRQ, which in turn defines the time in a circadian cycle. However, it is also possible that these phosphatases regulate the clock indirectly by dephosphorylating other proteins, such as by affecting the activity of the FRQ kinases. In the $r g b-1^{R I P}$ strain, its slow growth and developmental phenotype may also contribute to its clock phenotypes. But, we have previously shown that there is no direct relationship between severe growth and developmental phenotypes and the function of the clock (Yang et al. 2002, 2003).

The functions of the eukaryotic PP1 and PP2A are regulated by numerous regulatory subunits /Virshup 2000; Cohen 2002). Furthermore, it has been shown that PP2A can form complexes with CKII or a calciumcalmodulin-dependent kinase (Heriche et al. 1997; Westphal et al. 1998), suggesting that phosphorylation and dephosphorylation of cellular proteins are tightly coupled. Interestingly, both CKII and a calciumcalmodulin-dependent kinase were shown to be FRQ kinases in Neurospora (Yang et al. 2001, 2002), raising the possibility that the functions of CKII and CAMK-1 in FRQ phosphorylation are regulated by PP2A.

The roles of CKI and CKII appear to be conserved in various eukaryotic circadian systems (Kloss et al. 1998; Price et al. 1998; Sugano et al. 1999; Lowrey et al. 2000; Gorl et al. 2001; Lin et al. 2002; Yang et al. 2002, 2003; Akten et al. 2003). Recent evidence in Drosophila and Neurospora further demonstrated that the proteasomemediated degradation of the phosphorylated clock proteins are both mediated by a conserved F-box/WD40-repeat-containing protein (Grima et al. 2002; Ko et al. 2002; He et al. 2003). These studies suggest that the posttranscriptional regulators mediating phosphorylation and degradation of clock proteins may be the evolutionary links among different eukaryotic circadian systems. Therefore, it is tempting to speculate that the highly conserved PP1 and PP2A enzymes will play important roles in other eukaryotic circadian systems.

\section{Materials and methods}

Stains, culture conditions, and race tube assay

A $b d, a$ strain and a wild-type Neurospora strain (FGSC 987, 74-OR23-1A) were used as control strains in this study. Because both strains contained wild-type clocks, for simplicity, they were both called wild-type strains. All other strains described in this study contain the $b d$ mutation, except for the $r g b-1^{R I P}$ strain, which was described previously (Yatzkan and Yarden 1999). The FGSC 987 strain (without the $b d$ mutation) was used as the control strain in experiments described in Figures 4 and 5C, while the $b d, a$ strain was used as the control strain in the rest of the study. Liquid culture conditions were the same as described previously using medium containing $1 \times$ Vogel's and $2 \%$ glucose (Aronson et al. 1994). Conidiation rhythms were examined on race tubes containing glucose/ arginine medium $\left(1 \times\right.$ Vogel's, $^{2} .1 \%$ glucose, $0.17 \%$ arginine, $50 \mathrm{ng} / \mathrm{mL}$ biotin, and $1.5 \%$ agar). Densitometric analysis of race tubes and calculations of period length and phase were performed as previously described (Roenneberg and Taylor 2000).

Mutation of ppp-1 in Neurospora by repeat-induced point mutation A PCR fragment containing the PP1 ORF was cloned into pDE3dBH and introduced into the his-3 locus of 301-6 by transformation. A positive transformant was crossed with a wild-type strain. DNA sequencing was performed to identify strains in which the endogenous $p p p-1$ gene was mutated. The $b d, p p p-1^{R I P}$ strain grows on histidine-free medium and contains only one copy of the ppp-1 gene.

Expression of Myc-tagged PPP-1 and PPH-1 in Neurospora A PCR fragment containing the entire ORF and the $3^{\prime}$ UTR of PPP- 1 or PPH-1 was cloned into pqa.5Myc (He et al. 2003) to create pqa-MycPPP-1 or pqa-Myc-PPH-1. The resulting plasmids were transformed into a wild-type strain (301-6) at the his-3 locus. The expression of Myc-PPP-1 or Myc-PPH-1 in these transformants was confirmed by Western blot analysis using a monoclonal c-Myc antibody (9E10, Santa Cruz Biotechnology).

Immunoprecipitation, followed by dephosphorylation reaction For immunoprecipitation, $50 \mu \mathrm{g}$ of Neurospora total extracts of $f r q^{10}$, Myc-FRQ was mixed with $1 \mathrm{mg}$ extracts of wild type, Myc.PPP-1, wild type, Myc.PPH-1, or wild type strain. The extracts were then incubated at $4{ }^{\circ} \mathrm{C}$ for $2 \mathrm{~h}$ with the monoclonal c-Myc antibody $(2 \mu \mathrm{g}$; Santa Cruz Biotechnology). Subsequently, protein $\mathrm{G}$ agarose beads $(10 \mu \mathrm{L})$ were added, and the mixture was incubated at $4^{\circ} \mathrm{C}$ for $1-2 \mathrm{~h}$. After centrifugation, the agarose beads were washed four times with ice-cold extraction buffer and once with phosphatase buffer before they were resuspended in $30 \mu \mathrm{L}$ of phosphatase buffer and incubated at $30^{\circ} \mathrm{C}$ for $1 \mathrm{~h}$. Dephosphorylation reactions were stopped by the addition of SDS-polyacrylamide sample buffer and subjected to Western blot analysis.

\section{Acknowledgments}

We thank Lixin Wang for excellent technical assistance and Drs. Mark Mumby, Hongtao Yu, and Michael Young for advice. Supported by grants from National Institutes of Health and Welch Foundation to Y.L. and the Israel Science Foundation to O.Y. Y.L is the Louise W. Kahn endowed scholar in Biomedical Research at University of Texas Southwestern Medical Center.

The publication costs of this article were defrayed in part by payment of page charges. This article must therefore be hereby marked "advertisement" in accordance with 18 USC section 1734 solely to indicate this fact.

\section{References}

Akten, B., Jauch, E., Genova, G.K., Kim, E.Y., Edery, I., Raabe, T., and Jackson, F.R. 2003. A role for CK2 in the Drosophila circadian oscillator. Nat. Neurosci. 6: 251-257.

Aronson, B., Johnson, K., Loros, J.J., and Dunlap, J.C. 1994. Negative feedback defining a circadian clock: Autoregulation in the clock gene frequency. Science 263: 1578-1584.

Cambareri, E.B., Jensen, B.C., Schabtach, E., and Selker, E.U. 1989. Repeat-induced G-C to A-T mutations in Neurospora. Science 244: $1571-1575$. 
Cheng, P., Yang, Y., Heintzen, C., and Liu, Y. 2001a. Coiled-coil domain mediated FRQ-FRQ interaction is essential for its circadian clock function in Neurospora. EMBO J. 20: 101-108.

Cheng, P., Yang, Y., and Liu, Y. 2001b. Interlocked feedback loops contribute to the robustness of the Neurospora circadian clock. Proc. Natl. Acad. Sci. 98: 7408-7413.

Cheng, P., Yang, Y., Gardner, K.H., and Liu, Y. 2002. PAS domain-mediated WC-1/WC-2 interaction is essential for maintaining the steady state level of WC-1 and the function of both proteins in circadian clock and light responses of Neurospora. Mol. Cell. Biol. 22: 517-524.

Cheng, P., Yang, Y., Wang, L., He, Q., and Liu, Y. 2003. WHITE COLLAR1, a multifunctional Neurospora protein involved in the circadian feedback loops, light sensing, and transcription repression of $w c-2$. J. Biol. Chem. 278: 3801-3808.

Cohen, P.T. 2002. Protein phosphatase 1-Targeted in many directions. I. Cell. Sci. 115: 241-256.

Crosthwaite, S.K., Dunlap, J.C., and Loros, J.J. 1997. Neurospora wc-1 and $w c-2$ : Transcription, photoresponses, and the origins of circadian rhythmicity. Science 276: 763-769.

Denault, D.L., Loros, J.J., and Dunlap, J.C. 2001. WC-2 mediates WC-1FRQ interaction within the PAS protein-linked circadian feedback loop of Neurospora. EMBO I. 20: 109-117.

Dunlap, J.C. 1999. Molecular bases for circadian clocks. Cell 96: 271-290.

Froehlich, A.C., Liu, Y., Loros, J.J., and Dunlap, J.C. 2002. White Collar-1, a circadian blue light photoreceptor, binding to the frequency promoter. Science 297: 815-819.

Froehlich, A.C., Loros, J.J., and Dunlap, J.C. 2003. Rhythmic binding of a WHITE COLLAR-containing complex to the frequency promoter is inhibited by FREQUENCY. Proc. Natl. Acad. Sci. 100: 5914-5919.

Garceau, N., Liu, Y., Loros, J.J., and Dunlap, J.C. 1997. Alternative initiation of translation and time-specific phosphorylation yield multiple forms of the essential clock protein FREQUENCY. Cell 89: 469476.

Gorl, M., Merrow, M., Huttner, B., Johnson, J., Roenneberg, T., and Brunner, M. 2001. A PEST-like element in FREQUENCY determines the length of the circadian period in Neurospora crassa. EMBO J. 20: 7074-7084.

Grima, B., Lamouroux, A., Chelot, E., Papin, C., Limbourg-Bouchon, B., and Rouyer, F. 2002. The F-box protein slimb controls the levels of clock proteins period and timeless. Nature 420: 178-182.

He, Q., Cheng, P., Yang, Y., Wang, L., Gardner, K.H., and Liu, Y. 2002. White collar-1, a DNA binding transcription factor and a light sensor. Science 297: 840-843.

He, Q., Cheng, P., Yang, Y., He, Q., Yu, H., and Liu, Y. 2003. FWD1mediated degradation of FREQUENCY in Neurospora establishes a conserved mechanism for circadian clock regulation. EMBO J. 22: 4421-4430.

Heriche, J.K., Lebrin, F., Rabilloud, T., Leroy, D., Chambaz, E.M., and Goldberg, Y. 1997. Regulation of protein phosphatase 2A by direct interaction with casein kinase $2 \alpha$. Science 276: 952-955.

Kloss, B., Price, J.L., Saez, L., Blau, J., Rothenfluh, A., and Young, M.W. 1998. The Drosophila clock gene double-time encodes a protein closely related to human casein kinase Ie. Cell 94: 97-107.

Ko, H.W., Jiang, J., and Edery, I. 2002. Role for Slimb in the degradation of Drosophila Period protein phosphorylated by Doubletime. Nature 420: $673-678$.

Krebs, E.G. and Fischer, E.H. 1962. Phosphorylase b kinase from rabbit skeletal muscle. Methods Enzymol. 5: 373-376.

Lin, J.M., Kilman, V.L., Keegan, K., Paddock, B., Emery-Le, M., Rosbash, M., and Allada, R. 2002. A role for casein kinase $2 \alpha$ in the Drosophila circadian clock. Nature 420: 816-820.

Liu, Y., Garceau, N., Loros, J.J., and Dunlap, J.C. 1997. Thermally regulated translational control mediates an aspect of temperature compensation in the Neurospora circadian clock. Cell 89: 477-486.

Liu, Y., Loros, J., and Dunlap, J.C. 2000. Phosphorylation of the Neurospora clock protein FREQUENCY determines its degradation rate and strongly influences the period length of the circadian clock. Proc. Nat1. Acad. Sci. 97: 234-239.

Loros, J.J. and Dunlap, J.C. 2001. Genetic and molecular analysis of circadian rhythms in NEUROSPORA. Annu. Rev. Physiol. 63: 757-794.

Lowrey, P.L., Shimomura, K., Antoch, M.P., Yamazaki, S., Zemenides, P.D., Ralph, M.R., Menaker, M., and Takahashi, J.S. 2000. Positional syntenic cloning and functional characterization of the mammalian circadian mutation tau. Science 288: 483-492.

Price, J.L., Blau, J., Rothenfluh, A., Adodeely, M., Kloss, B., and Young, M.W. 1998. double-time is a new Drosophila clock gene that regulates PERIOD protein accumulation. Cell 94: 83-95.

Roenneberg, T. and Taylor, W. 2000. Automated recordings of bioluminescence with special reference to the analysis of circadian rhythms. Methods Enzymol. 305: 104-119.

Sugano, S., Andronis, C., Ong, M.S., Green, R.M., and Tobin, E.M. 1999. The protein kinase $\mathrm{CK} 2$ is involved in regulation of circadian rhythms in Arabidopsis. Proc. Natl. Acad .Sci. 96: 12362-12366.

Talora, C., Franchi, L., Linden, H., Ballario, P., and Macino, G. 1999. Role of a white collar-1-white collar-2 complex in blue-light signal transduction. EMBO J. 18: 4961-4968.

Virshup, D.M. 2000. Protein phosphatase 2A: A panoply of enzymes. Curr. Opin. Cell Biol. 12: 180-185.

Westphal, R.S., Anderson, K.A., Means, A.R., and Wadzinski, B.E. 1998 A signaling complex of Ca2+-calmodulin-dependent protein kinase IV and protein phosphatase 2A. Science 280: 1258-1261.

Yang, Y., Cheng, P., Zhi, G., and Liu, Y. 2001. Identification of a calcium/ calmodulin-dependent protein kinase that phosphorylates the Neurospora circadian clock protein FREQUENCY. J. Biol. Chem. 276: 41064-41072.

Yang, Y., Cheng, P., and Liu, Y. 2002. Regulation of the Neurospora circadian clock by casein kinase II. Genes \& Dev. 16: 994-1006

Yang, Y., Cheng, P., He, Q., Wang, L., and Liu, Y. 2003. Phosphorylation of FREQUENCY protein by casein kinase II is necessary for the function of the Neurospora circadian clock. Mol. Cell. Biol. 23: 62216228.

Yatzkan, E. and Yarden, O. 1995. Inactivation of a single-2A phosphoprotein phosphatase is lethal in Neurospora crassa. Curr. Genet. 28: 458-466.

. 1999. The B regulatory subunit of protein phosphatase $2 \mathrm{~A}$ is required for completion of macroconidiation and other developmental processes in Neurospora crassa. Mol. Microbiol. 31: 197-209.

Yatzkan, E., Szoor, B., Feher, Z., Dombradi, V., and Yarden, O. 1998. Protein phosphatase 2A is involved in hyphal growth of Neurospora crassa. Mol. Gen. Genet. 259: 523-531.

Young, M.W. and Kay, S.A. 2001. Time zones: A comparative genetics of circadian clocks. Nat. Rev. Genet. 2: 702-715.

Zeke, T., Kokai, E., Szoor, B., Yatzkan, E., Yarden, O., Szirak, K., Feher, Z., Bagossi, P., Gergely, P., and Dombradi, V. 2003. Expression of protein phosphatase 1 during the asexual development of Neurospora crassa. Comp. Biochem. Physiol. B. 143: 161-170. 


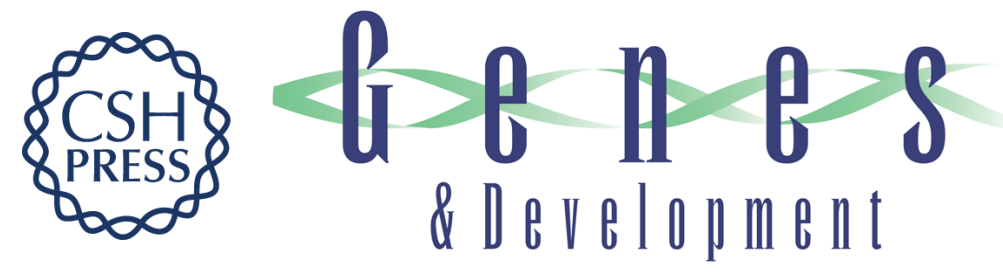

\section{Distinct roles for PP1 and PP2A in the Neurospora circadian clock}

Yuhong Yang, Qun He, Ping Cheng, et al.

Genes Dev. 2004, 18:

Access the most recent version at doi:10.1101/gad.1152604

Supplemental

http://genesdev.cshlp.org/content/suppl/2004/01/26/18.3.255.DC1

Material

References This article cites 41 articles, 23 of which can be accessed free at: http://genesdev.cshlp.org/content/18/3/255.full.html\#ref-list-1

License

Email Alerting Receive free email alerts when new articles cite this article - sign up in the box at the top Service right corner of the article or click here.

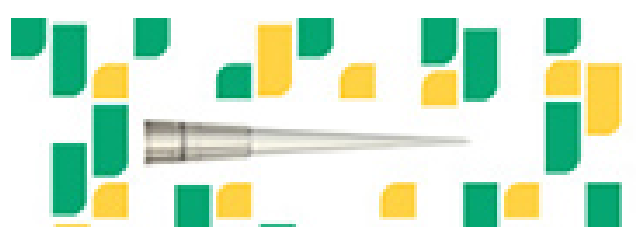

Focused on your science. 